\title{
CULTURAL ELEMENTS IN ELODIE LAWTON MIJATOVIĆ'S TRANSLATION OF SERBIAN FOLK TALES
}

\begin{abstract}
The aim of this paper is to describe how one of the first translators of Serbian folk tales, Elodie Lawton Mijatović, translated words and expressions which belong to Serbian culture, i.e. those that are culturally marked. The tales we decided to use for this analysis are Bash Chalek; or True Steel (Baš Čelik), The Wonderful Kiosk (Čardak ni na nebu ni na zemlji), Papalluga; or the Golden Slipper (Pepeljuga), The Golden-Fleeced Ram (Zlatoruni ovan) and Lying for a Wager (Laž za opkladu). Serbian cultural elements found in these tales include but are not limited to the following: objects typical of Serbian culture, common greetings, ways of addressing, curses, kinship terminology, social institutions and names. The translator resorted to various techniques, most commonly neutralization, or used cultural equivalents of the culturally marked words and expressions used in the Serbian original, but in some cases they are simply omitted. It is possible to conclude that the translator was aware of the cultural context of the tales, and that the use of the techniques mentioned above was overall justified.
\end{abstract}

Key words: translation techniques, cultural markedness, Serbian folk-tales, Elodie Lawton Mijatović

Regardless of the fact that Serbian folk poetry and prose have had a long tradition, they were virtually unknown in Western Europe until the early $19^{\text {th }}$ century, when some poems and stories became available in German, and later in English. Although folk poetry is better-known, folk prose also found its place.

The corpus for this paper was taken from the 1874 edition of Serbian FolkLore, a collection of folk-tales translated by Elodie Lawton Mijatović. It includes the following tales: Bash Chalek; or True Steel (Baš Čelik), The Wonderful Kiosk (Čardak ni na nebu ni na zemlji), Papalluga; or the Golden Slipper (Pepeljuga), The GoldenFleeced Ram (Zlatoruni ovan) and Lying for a Wager (Laž za opkladu).

According to William Denton, the author of the Introduction and the editor, most of the tales were taken from Srpske narodne pripovijetke, collected by Vuk Stefanović

\footnotetext{
* Faculty of Philology, University of Belgrade, Studentski trg 3, 11000 Belgrade, Serbia; e-mail: nenad. tomovic@fil.bg.ac.rs
} 
Karadžić, published in Vienna in 1853. It is important to note that Karadžić was not just someone who collected these tales; he was also a reformer of the Serbian literary language, and it is certain that he adapted the tales he had collected to fit the linguistic standards he himself had set (Mojašević 1953 as cited in Vukobrat 1992: 8). The same author states that Karadžić also replaced certain words with those he deemed better, clarified obscure details and adapted the original texts so as to place them into what he considered to be the ideal framework of folk narrative. All these tales are written in what is technically known as Modern Serbian, which is based on the variety spoken in the area where Karadžić's was born and is not much different from the language spoken today, but there are some differences in the vocabulary and certain verb forms that nowadays seem archaic.

The tales discussed in this paper are not exclusively Serbian. There are both motifs and entire plots that can be found in European folk tales (Deretić 1983: 150), and it is thus possible to state that they belong to common European cultural heritage. On the other hand, folk tales always contain cultural elements typical of the community which adopted and adapted them and are important elements of national heritage. This holds true for the tales analyzed in this paper, which contain numerous elements typical of Serbian culture.

The translator of the tales we are analyzing is Elodie Lawton Mijatović (also spelled Miyatovi[t]ch or Mijatovics, or in modern Serbian, Mijatović (Markovich 2010: 104); for the purposes of this text, her name will be spelled as Mijatović since this variant is most commonly used today). An author, journalist and political activist, she married Čedomilj Mijatović, a notable Serbian politician, and later learned the Serbian language. She was interested in Serbian culture and history, and even wrote several books about Serbia. She also translated several books from and into Serbian (Markovich 2010; Vukobrat 1992).

The collection was edited by Rev. William Denton, who wrote several books about Serbia, and was well-acquainted with the language and culture. In the Introduction, Denton describes his editing and provides information about what was changed, and to a certain degree, about the translator's command of Serbian: "...I have, however, preserved, as far as possible, the literality of her version, and have limited myself to the addition of a few notes to the text and to occasional corrections of style, rendered necessary by the translator's habit of thinking and writing in another language". (Mijatovich 1874: 2). We can thus conclude that both the translator and the editor had good command of Serbian, and that they were both well-acquainted with Serbian culture and folklore.

The cultural elements discussed here are viewed from the point of view of translation theory. Since there are numerous authors who offer various classifications 
of translation techniques, procedures and methods, we have decided to use common terminology used in translation theory, while techniques particular to certain authors will be further explained.

We will start with the titles of the stories. Out of five titles, two were translated literally, i.e. The Golden-Fleeced Ram (Zlatoruni ovan) and Lying for a Wager (Laž za opkladu). The other three titles were problematic, and the translator had to employ different techniques. The most famous tale is Bash Chalek; or True Steel. Its original title refers to the main protagonist (Baš Čelik, or True Steel in the translation), whose name is ambiguous in Serbian. The word baš is both an intensifier, which means 'very', 'true' 'real' etc. There is also a homonymous form of Turkish origin (baş), which refers to a leader, but it can also be interpreted metaphorically as 'tough', 'strong' or even 'hero' (Vukobrat 1992: 12). The other part of the name (Čelik) refers to steel, although it can be used metaphorically to denote a tough person. Since it is impossible to pinpoint the meaning of the character's name in Serbian, the translator obviously decided to both transcribe it, which preserves the name, and to translate it, although we can say that his name is lost in translation, regardless of the translator's knowledge and efforts. The Wonderful Kiosk (Čardak ni na nebu ni na zemlji) lost most of the original meaning. The first word of the title, čardak, refers to typical Turkish-style houses that can still be found in the Balkans. Although English dictionaries do not register the word chardak, it can be found in some modern brochures or texts about Ottoman architecture. The translator decided to replace the word čardak with kiosk, which refers to "an open pavilion or summerhouse of light construction, [...] common in Turkey and Persia" (OED), which, in Newmark's terms, ${ }^{1}$ can be described as the cultural equivalent of the Serbian word. In this case, the picture of the structure is changed. While a čardak is a type of house in which one can dwell and sleep, a kiosk is a light structure which provides shelter from the sun or rain, and cannot be lived in. If fact, the čardak is described as a place with several rooms, and there are indications that it is as spacious as a castle. The only element of meaning which is preserved is its Turkish origin. The rest of the title "ni na nebu ni na zemlji" means "neither in heaven nor on earth". In the tale, the kiosk is actually hanging somewhere in mid-air and can be described as something supernatural or magical, which is why the translator decided to render it as wonderful. This adjective does describe the čardak, since it means "full of wonder; such as to excite wonder or astonishment; marvelous; sometimes used trivially = surprisingly large, fine, excellent, etc." (OED).

The last tale whose title should be mentioned is Papalluga; or the Golden Slipper (Pepeljuga). Papalluga approximates the pronunciation of the main protagonist, or in

\footnotetext{
${ }^{1}$ According to Newmark (2006: 82-83), a cultural equivalent is "an approximate translation where a SL (source language) cultural word is translated by a TL (target language) cultural word".
} 
Hlebec's terms (Hlebec 2017: 12-13), the translator transcribed it. The original name Pepeljuga is derived from the word pepeo ('ash', 'cinders'), and can be translated as 'scullery-maid' or 'cinder-woman', or simply 'a woman servant who does menial tasks'. The Serbian version uses the word pepeljuga as a common noun, which is obvious from the fact that it is not capitalized. However, Pepeljuga can be used as a proper name and corresponds to Cinderella, both in terms of etymology and of the tale itself. The translator and/or the editor were aware of this, which is obvious from the English text: "...but as she had worked so much in the house, carrying water, cooking, washing dishes, sweeping the house, and doing all sorts of house-work, and had very much to do about the fire and cinders, her stepmother and half-sister called her 'Papalluga' (Cinderella)" (Mijatovich 1874: 61), which proves the translator was aware of the fact that transcription is insufficient.

The plot of this tale is very similar to the Cinderella Western readers are familiar with, and the main differences are the place where she meets the prince (church service) and her footwear (slipper, unlike the glass shoe from the Western version). However, the other part of the title, where the golden slipper is mentioned, might be described as the translator's addition of a motif from the story itself, although it has to be noted that the slipper was not described as golden, neither in the original text nor in the translation. In this case, the translator added both that the slipper was golden, which is probably what she thought logical. The clothes that the main protagonist wore when she met the prince were made of gold, and Mijatović must have concluded that her slippers were made of gold, too, although this assumption can only be implied.

Having described how the titles of the tales were translated, which may deserve to be analyzed in a separate paper, we can move on to the tales and describe what methods, procedures and techniques the author used to describe cultural elements, some of which appear several times.

We can start with several proper names that the translator dealt with in different ways. Apart from Papalluga and Bash Chalek, which have already been mentioned, there are other two names that caught our attention. One of them is Mara, a common Serbian nickname for the name Marija, and Mijatović simply decided to adapt it to English. Thus, Mara became Mary. Another proper name that appears in the English translation and is derived from an adjective, Beardless, does not have the status of a proper name in Serbian, as suggested by the small letter $c$ in the Serbian spelling. It is ćosa, a character which appears in Lying for a wager. A footnote (Mijatovich 1874: 107) provides the reader with the explanation that Beardless is the common personification of craft and sharpness in Serbian folk tales.

Concerning other cultural elements, we will move on to the words which refer to monarchies and monarchs and appear in every tale, with the exception of Lying for 
a Wager. The most commonly used monarch's title in the original text is car ('czar, tsar'), which is almost always translated as 'king' and once as 'a great king' (in Bash Chalek). The Serbian word car refers to the highest rank a monarch can get (RSJ 2007) or emperor, while the English translation 'king' seems to belittle the meaning of the Serbian noun. However, it does not have to be the case. Since both the translator and the editor had to adapt certain elements of a culture their readers were not familiar with, which is also evident from the other examples that are to be discussed later, it is possible to assume that the monarch's title was simply adapted to correspond to the usual folk tale pattern in English, where monarchs in tales are usually kings. If we accept this hypothesis, we can say that Mijatović opted for cultural equivalents. The translator followed the same pattern when translating the words carstvo ('empire') and carević ('prince', 'a king's son').

Another interesting aspect of the translation is religion and its elements incorporated in sayings, greetings and expressions. Serbs of that time belonged exclusively to the Eastern Orthodox Church, and certain rites are thus somewhat different from those typical of Western churches. We can start with the word leturdija (modern use: liturgija; modern English liturgy (n.d.), which refers to the Eucharistic celebration (Collins English Dictionary, 2014) or the service of the Eucharist (Random House Kernerman, 2010) typical of the Eastern Church, and is commonly translated as liturgy. In this case, however, Mijatović used the word service, which has a more generalized meaning, and is an example of both functional and descriptive equivalence. This word choice is justified for two reasons - both the narrator and the characters use vernacular, and she might also have wanted to avoid specifying the differences between the churches.

An interesting example of a translation technique can be seen in the following example: “...pa mene pošlju Bogu po vodicu." - ..."and they sent me to heaven to bring some holy water." In this example, the translation differs from the original because the Serbian sentence means 'they sent me to God to get [some holy] water. Bog refers to God, but Mijatović decided to replace God with his alleged dwelling-place. Since this technique cannot be found in relevant literature, we will call it metonymy in translation. The same example also contains an addition - the Serbian word vodica is a diminutive and refers to water, but Mijatović had to add holy so as to explain what kind of water the character is supposed to bring. The diminutive was not used in the translation and was replaced with the hyperonym water.

God is also mentioned in the Serbian greeting Pomoz'Bog and the answer Bog ti pomogao. This greeting is similar to the German greeting grüß Gott, and Mijatović seems to avoid turning it into a common greeting as she translates it as 'God bless you' and 'God help you', while the answers are 'God bless you, too', and 'God help thee 
also', respectively. The greetings used in the English translation preserve the religious element of the original, although they sounded a bit archaic even when the translation was made.

It is possible to say that one mention of god was translated by using compensation.

A on joj srdito odgovori: "Idi s Bogom, kad mi pomoći ne možešs."

He answered, somewhat angrily, 'Go your way, in God's name!'

The Serbian sentence contains the expression idi s bogom, which literally means 'go [away] with god'; it is used when the speaker is irritated and wants to tell someone to go away. The English phrase in God's name is used after the main idea ('go your way') and since it expresses the speaker's anger, we can conclude that the effect of both utterances is the same.

On the other hand, the concept of god is omitted in certain phrases. One of them is "Bog ti pomogao kad si nam drug", which is translated as "Welcome! if thou art of our company!" In this case, the expression 'bog ti pomogao' is also a response to a greeting, although the greeting is not the traditional 'pomoz' bog', but 'dobra večer', which is equivalent to 'good evening'. There is another sentence in the original text where god is also omitted. The sentence reads: "Kako se ti zoveš, boga ti, po imenu?" and it is translated as "Now tell me, what is your name?" Although 'boga ti' can often be translated as 'by god', the translator probably decided to keep the conversation informal and devoid of religious connotations. Another instance where god is omitted is: "[Idi, sinko, opet iza sela], ne bi li te Bog namerio na onu devojčicu," which was translated as "Perhaps you will again meet the little girl". Although the original sentence had to be paraphrased, the purpose clause of the original text ("ne bi li te Bog namerio na onu devojčicu") contains the word god. The translation again excludes the divine component, although it is difficult to identify the reason.

The text features two mythical monsters - aždaja and zmaj. Although these words can refer to the same creature (RSJ 2007), the translator decided to make a clear distinction between them. Aždaja is translated as alligator, while zmaj is translated as dragon. Both creatures are reptiles, and the translator obviously wanted to preserve this semantic feature. However, she did not use words like wyvern or firedrake to refer to one of these words, but opted for a simple, although slightly inappropriate equivalent, and aždaja became an alligator, which is not a mythical creature but a reptile whose habitats are the United States and China.

Curses are usually not literally translated, but in Papalluga, that is exactly how Mijatović deals with an interesting one.

Maćeha poviče: ,Iš, orao te odnio!"

The stepmother shouted, 'Go away! may the eagle fly away with you!' 
Although the English translation might sound a bit odd, it actually represents the gist of many Serbian curses. Serbian curses can generally have different kinds of illocutionary force (Ristić 2010: 199).

Curses can be associated with vulgar or crude language, and this kind of language sometimes appears in Serbian folk literature, our corpus included. To illustrate this, we will provide a passage from Lying for a Wager and the English translation:

...te se privučem blizu, pa potegnem lisicu nogom u stražnjicu, a ona se uplaši, pa od straha p.. e, $i$ isp.. e tefter; kad ga ja otvorim, a to u njemu piše: meni pogača, a ćosi g.. .

Then I approached slowly and struck the fox furiously*, and he began to run, and, in running, dropped* a little book from his pocket. I opened the book, and there I read, "The whole loaf is for me, and Beardless is to get nothing*!

The problematic words are printed in bold in the Serbian original, although most of them are actually written with dots to replace foul language. However, Mijatović decided to simply omit the words or to replace them with a neutral word or phrase, and these parts are marked with an asterisk. The first word that Mijatović finds offensive is stražnjica, which can be translated as 'backside', 'bottom', 'buttocks', 'posterior', 'rump' etc. Mijatović deleted the word, and the action is thus less offensive. The next part of the Serbian text should be written as follows: "...pa od straha prdne, i isprdne tefter". The verb prdnuti is vulgar, and it means 'to break wind'. The other verb, isprdnuti, is akin to the previous one, although the prefix changes its meaning. It can roughly be translated as 'to expel something while breaking wind' and it is understandable why the translator focused on the fact that the fox had dropped the book and decided to omit the vulgar component. Finally, the part of the sentence that should actually be written "meni pogača, a ćosi govno" is translated euphemistically, since the last word, i.e. govno, is very offensive in Serbian, and it refers to excrement. On the other hand, govno can also be used metaphorically, and the phrase "a ćosi govno" means that the character will get nothing.

Some other elements of culture and/or cultural words are also omitted in certain cases, usually if they are difficult to translate or if there is no equivalent in English. Words like buzdovan ('mace'), plandište (a shady place where livestock can rest), mučnjak (a box where milled grain or flour is collected), pregršt ('handful') or jasle ('crib' [for cattle; a rack for fodder], 'manger') do not appear in the translation. We will provide the sentences in which they appear, their translations and try to explain why they were omitted:

...udari malo buzdovanom u leđa da se odmah s konja premetnuo...

....and struck his eldest brother slightly in the back... 
... a kad na podne goveda poliježu u plandištu

....at midday... [cattle not mentioned]

Ćoso ustane, pa razgrne đetinje brašno u mučnjaku, a đetetu reče da donosi vodu u pregrštima.

Beardless got up and began to mix the flour with water, which the boy brought him.

...u kojoj je bio jedan vran konj za jaslima privezan...

... where a black horse stood ready to be mounted...

Since Mijatović was competent in Serbian, it is possible to assume that she decided not to translate buzdovan because the focus of the description was the fact that one of the protagonists got struck, while the weapon was probably an unnecessary detail. We can assume that the reason for omitting jasle and pregršt was the same, i.e. that the translator wanted to spare the reader unnecessary details. On the other hand, words like plandište and mučnjak might have been left out because the translation could not find their English equivalents or thought these words would have to be explained to the reader. In fact, omitting the word plandište necessitated another omission. Since the word refers to a place where cattle can rest, it was necessary to adapt the scene and leave the cattle out, too.

The omission of certain cultural words does not mean that Mijatović always resorted to this technique. Let us now have a look at a few more words and their translations:

$$
\begin{aligned}
& \text { akov-barrel } \\
& \text { zubun-overcoat } \\
& \text { kalfa-salesman } \\
& \text { ruča - dinner }
\end{aligned}
$$

When translating culture-specific words, it is often necessary to widen the meaning of the word used in the target language, which is the case with several cultural words in the corpus. One of them is akov (about 50 1), a unit of measurement, translated as 'barrel', and in this case it refers to the quantity an average barrel can hold. The noun zubun denotes a short jacket worn by common people in the past, and it was translated as overcoat. Kalfa refers to a journeyman, a worker skilled in a particular craft who does not yet have his own business, but it can also denote a shopkeeper's assistant. Since the context in which the word kalfa was used makes it clear that the second meaning is appropriate (shopkeeper's assistant), Mijatović opted to translate it as 'salesman'. In these cases, the meaning of each word was widened in the target language, although we can say that it was at the same time narrowed in the 
case of kalfa. Finally, in the case of the noun ručak, the translator decided to narrow the meaning of the translation and used the word dinner. The Serbian word ručak can be translated as 'lunch' or 'dinner', but since it denotes the largest meal of the day, the word choice is justified.

There is also an interesting simile that was retained in the translation. The expression čuvati kao oči u glavi means 'to hold dear', 'to guard' etc. It is used in the sentence “...kćer, koju je [...] čuvao kao oči u glavi”, and it was translated as follows: "...he cared for her as for his own eyes." Although there were several other solutions, the translator decided to translate it literally and the original simile was retained.

Since the corpus contains five tales and is of considerable length, it was not possible to record every translation technique. On the other hand, an overview of the translation techniques provides an insight into how a $19^{\text {th }}$-century translator without formal education in the field of Slavic studies or linguistics managed to cope with a difficult task of translating a collection of tales created in a relatively unknown culture into English. The translator managed to find a good balance between presenting important cultural elements to the English reader and adapting them when their meaning was not crucial for the understanding of the text. Overall, the translation seems to reflect the translator's knowledge of the language and culture, that it is adequate concerning the audience and that it can be used even today because the language reflects the zeitgeist, or the spirit of the age.

\section{References}

Collins English Dictionary - Complete and Unabridged. 12 ${ }^{\text {th }}$ edition (2014). [1991, 1994, 1998, 2000, 2003, 2006, 2007, 2009, 2011, 2014]. (4 October 2019) $<$ https://www.thefreedictionary.com>.

Deretić, J. (1983). Istorija srpske književnosti. Beograd: NOLIT.

Hlebec, B. (2017). Prevodilačke tehnike i postupci. Beograd: Čigoja štampa.

Markovich, S. G. (2010). Anglophiles in Balkan Christian States (1862-1920). Balcanica, XL, 95-145.

Mijatovich, E. L. (1874). Serbian Folk-Lore. London: W. Isbister \& Co.

Mojašević, M. (1953). O Vukovoj stilizaciji srpskih narodnih pripovedaka. Zbornik Etnografskog muzeja u Beogradu - 1901-1951. Beograd: Etnografski muzej, 300-315.

Newmark, P. (2006). A Textbook of Translation. London: Longman.

OED: Oxford English Dictionary. 1989. Second Edition with the Addition Series 1993-7. CD-ROM version 3.00, 2002. 
RSJ: Rečnik srpskoga jezika. (2007). Novi Sad: Matica srpska.

Random House Kernerman Webster's College Dictionary. (2010). (4 October 2019)<https://www.thefreedictionary.com>.

Ristić, S. (2010). Diskurs psovki u srpskom jeziku. In: V. Vasić (ed.), Diskurs i diskursi. Zbornik u čast Svenke Savić, Novi Sad: Filozofski fakultet, 195-212.

Vukobrat, S. (1992). Englesko-srpske književne veze. Beograd: Naučna knjiga. 